\title{
Application of Geo-Informatics for Soil Nutrient and Jute Fibre Quality Mapping in Barasat-II Block of West Bengal, India
}

\author{
B. Saha*, Koushik Manna, S.C. Saha and Saptarshi Sarkar
}

ICAR-National Institute of Research on Jute and Allied Fibre Technology, 12 Regent Park, Kolkata - 700 040, India

*Corresponding author

\begin{abstract}
A B S T R A C T
Keywords

Soil, GPS, GIS, Soil fertility maps, Fibre Quality maps

Article Info

Accepted:

20 November 2018

Available Online:

10 December 2018

Soil is non-renewable natural resource and supports all the lives on earth. Soil nutrients are the major contributors towards soil fertility and cater to the needs of essential elements of plant. Jute is one of the important cash crops of West Bengal. Jute fibre quality is very much dependent on soil nutrients. A detailed soil nutrient status and Jute fibre quality of the Barasat-II block of North 24 Parganas District of West Bengal was investigated during 2017-18. Geo-referenced (GPS based) composite surface soil samples $(15 \mathrm{~cm})$ and jute fibre samples were collected from seven Gram-panchayets of Barasat-II block. Soil samples were analyzed for $\mathrm{pH}$, OC (\%) and available N, P, K, Ca. Most of the soils were found to be clayey in texture. Jute fibre quality parameters strength and fineness were analyzed. A strong positive correlation between soil fertility parameters and fibre quality parameters were observed. The thematic maps of soil fertility and jute fibre quality (fineness, strength) were developed for facilitating decision making toward comprehensive development of jute sector.
\end{abstract}

\section{Introduction}

In 21st century, geospatial technologies have emerged as very useful and effective tool in diverse application and have been found to be advantageous over conventional methods of soil surveys. These geospatial methods are used to record, store, and retrieve data from many soil observations including their location co-ordinates (latitude, longitude). Geographic Information Systems (GIS), and Global Positioning Systems (GPS) have added new approaches for analysing geo-coded data for making all kinds of predictions. The
Global Positioning System (GPS) is a satellitebased radio-navigation system owned by the government of United States and operated by the United States Air Force. It is a global navigation satellite system that provides the exact position of an object on the earth surface in terms of geographical co-ordinates. Currently, there are about 29-32 usable GPS satellites broadcasting radio signals toward Earth. The signals contain approximate and precise information about the satellite's position in its orbit around Earth. As a result of its design, this constellation of GPS satellites provides at least four satellites at any 
moment in time as viewed from any point on the Earth's surface (Hofmann-Wellenhof et al., 2001). A GIS is "an organized collection of computer hardware, software, geographic data, and personnel designed to efficiently capture, store, update, manipulate, analyze, and display all forms of geographically referenced information"(Redlands, 1990). Fertility of soil plays important role in increasing crop production in the soil. It contributes not only through supply of nutrients but also through their efficient management. It is generally believed that the quality of the jute fibre largely depends on retting process, which is essentially microbiological and biochemical in nature. Besides retting, soil parameters also influence jute quality. The influence of soil parameters on quality of jute fibre have never been studied elaborately. Keeping in view of above, influence of soil parameters like Nitrogen, Phosphorus, Potassium, Calcium, Organic Carbon, $\mathrm{EC}$ and $\mathrm{pH}$ on jute fibre quality like fineness and strength need to be assessed. GPS and GIS based soil fertility maps have been prepared in different areas of West Bengal by Different Organization. But no such work has been done for the Barasat-II block, North24 Parganas. Therefore, an attempt has been made in present study to prepare GPS and GIS based soil fertility and fibre quality maps of Barasat-II block in order to find out the effect of soil fertility status on jute Fibre Quality.

\section{Study area}

The district North 24 Paganas is located in southern part of West Bengal. The district comprises five subdivisions: Barrackpore, Barasat Sadar, Basirhat, Bangaon and Bidhannagar. There are twenty two community development (CD) blocks in the district. Barasat II is a community development block that forms an administrative division in Barasat Sadar subdivision. Barasat II CD Block is located between latitude $22^{\circ} 43^{\prime} 6.14^{\prime \prime}$ north to $22^{\circ} 36^{\prime} 11.42^{\prime \prime}$ north and longitude 88 $26^{\prime} 21.33^{\prime \prime}$ east to $88^{\circ} 37^{\prime} 41.55^{\prime \prime}$ east bounded by Barasat I CD Block in the north, Deganga and Haroa CD Blocks in the west and Rajarhat CD Block in the south. It is part of the North Hooghly plain land with alluvial soil located in the lower Ganges Delta and covers area of 114.04 $\mathrm{km}^{2}$. The Bidyadhari River forms the eastern boundary of Barasat II CD Block with Deganga CD Block, and as such it is partly in the North Bidyadhari Plain (Fig. 1). The Block has 1 panchayat samity, 7 gram panchayats (GP), 109 gram sansads (village councils), 78 mouzas and 77 inhabited villages and a municipality: Madhyam gram. Gram panchayats of Barasat II block are: Chandigarh-Rohanda, Falti Beliaghata, Kemia Khamarpara, Kirtipur I, Dadpur, Kiritipur II and Shason (Fig. 1). The average annual rainfall in the area is $1159 \mathrm{~mm}$, temperature varies from $10^{\circ} \mathrm{C}$ to $40^{\circ} \mathrm{C}$ and humidity varies from $50-90 \%$. Thus the area shows the characteristics of the tropical humid climate.

As per 2011 Census of India Barasat II CD Block had a total population of 2,00,918, of which 1,88,294 were rural and 11,994 were urban. Agriculture is the main livelihood of the people of the district North 24 Parganas. The regional homogeneity with the sufficient rainfall is favourable for the prosperity of Agriculture. Agriculture supports the economy of North 24 Parganas, on a large scale. Rice, jute, coconuts, potatoes, wheat and rapeseed are the major crops produced here (Table 1).

Barasat-II CD Block produced Aman paddy, Boro paddy, Aus paddy, wheat, jute, potatoes. pulses, oilseeds and vegetables (Table 1). Good quality fertile soil of Barasat-II block, adequate rainfall and well irrigation facility are main reasons for cultivation of jute by progressive farmers as one of the major economic crops. 


\section{Materials and Methods}

At first Block and GP map of Barasat-II block were geo-referenced with WGS84 datum and UTM Projection. The geo-referenced maps were digitized along with Block and GP boundary in ARC GIS software by creating personal geodatabase and feature classes (polygon feature) for preparing the vector image (.shp). Geo-referenced (GPS based) composite surface soil samples from $15 \mathrm{~cm}$ depth were collected from farmers' field during survey of bio-physical parameters. After harvesting of Jute, fibre samples (georeferenced) were collected from respective farmers' fields of 7 Gram-panchayats of Barasat-II block. All the location coordinates were saved (.gpx) by hand held GPS. Then the processed soil samples were analyzed for $\mathrm{pH}$, EC, organic carbon, available nitrogen, available phosphorus, available potassium and available calcium. The $\mathrm{pH}$ (1:2.5:: soil:water) of soil was measured as described by Jackson (1973). Soil organic carbon was determined by wet digestion method of Walkley and Black (1934) as described by Jackson (1973). Available soil nitrogen content was estimated by alkaline potassium permanganate method as outlined by Subbaiah and Asija (1956). Available phosphorus content of soil samples were estimated by Bray's No. 1 method (Bray and Kurtz, 1945) using spectrophotometer. Available potassium of soil samples were determined by extracting with neutral normal ammonium acetate extract (soil:extractant: 1:5) and subsequent estimation with flame photometer (Jackson, 1973). The calcium in ppm was measured by Atomic Absorption Spectrophotometer. The fibre samples of jute were analysed for strength and fineness according to BIS-2003 Grading System. NIRJAFT Bundle Strength Tester and Airflow Fineness Tester were used for determination of jute fibre strength and fineness respectively. Finally, all the GPS (latitude, longitude) and attribute data (soil, fibre) were joined with GP boundary in Arc
GIS software to produce thematic soil fertility and jute fibre quality maps.

\section{Results and Discussion}

\section{Soil pH and electrical conductivity}

The Soils are neutral $(\mathrm{pH}$ 6.53-7.14) in reaction for all the GPs. The Highest $\mathrm{pH}$ (7.14) was found in GP RohandaChandigharh and the lowest $\mathrm{pH}$ (6.15) in Sasan GP of Barasat Block II. The electrical conductivity (EC) of all the GPs remains within safe limit with no salinity hazard (Table 2). The highest mean conductivity was observed in Sasan GP $(0.26 \mathrm{dSm}-1)$ followed by GP Kritipur-II $(0.2 \mathrm{dSm}-1)$ and lowest in Sasan GP (0.08dSm-1). Spatial variation in values of $\mathrm{pH}$ and $\mathrm{EC}$ in different GPs has been depicted through thematic maps (Fig. 1 and 2).

\section{Organic carbon}

The mean Organic Carbon (\%) of seven GPs of Barasat-II block varied within the range of $0.41-0.68 \%$. Highest mean Organic carbon was found $0.68 \%$ in case of Dadpur GP followed by Falti Beliaghata. In case of Sasan, Kemia Khamarapara and Kritipur-IGP medium level of organic carbon (\%) were found with values $0.61 \%, 0.55 \%$ and $0.54 \%$ respectively. Whereas, GP like Kritipur-II and Rohanda-Chandighrh showed lower mean organic carbon (\%) with 0.49 and $0.41 \%$ respectively (Table 2 and Fig. 3).

\section{Available macronutrients}

Soils are medium to high in available Nitrogen (Table 3, Fig. 4). The highest mean (565 $\mathrm{kg} / \mathrm{ha}$ ) available Nitrogen was observed in Dadpur GP flowed by Kritipur-I (455kg/ha). However, lowest mean available soil Nitrogen content $(301 \mathrm{~kg} / \mathrm{ha})$ was recorded in Rohanda Chandigharh GP followed by Falti Beliaghata $(375 \mathrm{~kg} / \mathrm{ha})$ and Sasan $(390 \mathrm{~kg} / \mathrm{ha})$ respectively. High value of nitrogen content may be due to 
mineralisation of nitrogen at the jute rhizosphere and crop residues. GP Dadpur, Kemia Khamapara and Kritipur-I of Barasat Block II were high in mean available phosphorous representing $39.5 \mathrm{~kg}$ ha- $1,23 \mathrm{~kg}$ ha-1 and $26 \mathrm{Kg}$ ha-1 respectively while Kritipur-II, Sasan and Falti Beliaghata contained medium mean available phosphorous (15-20 kg ha-1) (Table 3, Fig. 5). The highest available phosphorous content was recorded in Dadpur GP (39.5 kg ha-1) whereas, the lowest available phosphorous content $\left(8 \mathrm{~kg} \mathrm{ha}^{-1}\right)$ was recorded in Rohanda Chandigharh GP. The mean available potassium of all GP's was low except Dadpur. The highest available potassium (260 kg ha-1) was found in Dadpur GP (Table 3 and Fig. 6), whereas, lowest potassium content (110 kg ha1) was recorded in Rohanda Chandigharh GP. The available calcium of the block Barasat -II was low which may be attributed to higher crop uptake in rice based cropping system. The highest available soil calcium (565 ppm ) was found in Dadpur GP followed by Krtitipur-I and Kemia Khamapara (Table 3, Fig. 7), while lowest amount of available calcium was recorded in RohandaChandigharh (270 ppm).

\section{Quality parameter of jute fibre samples}

In commercial point of view, jute fibre quality is the most important criteria. Higher value of strength and lower value of fineness indicate the good quality of jute fibre. The highest mean strength of jute fibre was recorded in Dadpur GP (25.1 g/tex) followed by krtipur-I (21.9 gm/tex) and lowest value of fibre strength (16.5 gm/tex) was observed in Rohanda- Chandigharh (Table 4). The highest value of fibre strength may be due to uptake of Potassium, calcium and phosphorous as soil of dadpur contained high potassium, calcium and phosphorous (Table 3, Fig. 8). The fineness of jute fibre value revealed that lowest fineness value (2.5 tex) was observed in Dadpur followed by Krtitipur -I (Table 4, Fig. 9).

The finer fibre may be due to presence of higher organic carbon (\%) in soil at Dadpur and kritipur GP. The quality of jute fibre was deteriorated due to the low content of potassium in soil as well as plant in case of Sasan, Rohanda- Chandigharh and Falti Beliaghata. The similar views are corroborated with the findings of Tamang (1995) who found that the levels of $\mathrm{K}$ had very strong corelation with strength of Jute fibre (Table 3, Table 4). Organic carbon (\%) and available NP-K of soil with fibre yield and quality showed that available nitrogen is strongly related to organic carbon content of the soil, which in turn had positive effect on yield of fibre (Table2, Table3). Drewink (2006) reported that as nitrogen played a key role in metabolic activities of plant, it affected the plant growth and fibre yield and quality.

Table.1 Production of Principal Crops in North 24 Parganas

Production of Principal Crops in N 24 Parganas

Area in thousand hectres

Production in thousand tones

\begin{tabular}{|l|c|c|c|c|c|c|}
\hline \multirow{2}{*}{ Crops } & \multicolumn{2}{c|}{$\mathbf{2 0 1 0 - 1 1}$} & \multicolumn{2}{c|}{ 2011-12 } & \multicolumn{2}{c|}{ 2012-13 } \\
\cline { 2 - 7 } & Area & Production & Area & Production & Area & Production \\
\hline Rice & 223.7 & 606.6 & 221.5 & 597.5 & 217.5 & 649.1 \\
\hline Wheat & 7.4 & 19.7 & 7.2 & 20.3 & 7.2 & 19.9 \\
\hline Other Cereals & 0.1 & 0.4 & 0.2 & 0.5 & 0.2 & 0.5 \\
\hline Total Cereals & 231.2 & 626.7 & 228.8 & 618.3 & 224.9 & 669.5 \\
\hline Pulses & 7.8 & 7.1 & 9.6 & 9.4 & 12.0 & 9.6 \\
\hline Total Food grains & $\mathbf{2 3 9 . 0}$ & $\mathbf{6 3 3 . 8}$ & $\mathbf{2 3 8 . 4}$ & $\mathbf{6 2 7 . 7}$ & $\mathbf{2 3 6 . 9}$ & $\mathbf{6 7 9 . 1}$ \\
\hline Oilseeds & 45.6 & 63.3 & 50.9 & 55.0 & 57.2 & 77.7 \\
\hline Jute(C) & 50.2 & 955.0 & 56.7 & 1019.5 & 47.4 & 754.3 \\
\hline Potato & 9.2 & 331.3 & 7.0 & 205.6 & 6.4 & 205.2 \\
\hline
\end{tabular}


Table.2 Soil chemical parameters of different Gram Panchyate of Barasat -II

\begin{tabular}{|l|l|l|l|l|l|l|l|}
$\begin{array}{l}\text { SI. } \\
\text { No. }\end{array}$ & GP & pH & Mean & $\mathbf{E C ( d s / m )}$ & Mean & $\begin{array}{l}\text { Organic } \\
\text { carbon }(\%)\end{array}$ & Mean \\
\hline $\mathbf{1}$ & Dadpur & $6.53-7.23$ & 6.8 & $0.07-0.10$ & 0.09 & $0.59-0.79$ & 0.68 \\
\hline $\mathbf{2}$ & Sasan & $6.15-7.09$ & 6.7 & $0.06-0.10$ & 0.08 & $0.42-0.68$ & 0.56 \\
\hline $\mathbf{3}$ & KemiaKhamarpara & $6.23-7.08$ & 6.6 & $0.07-0.12$ & 0.09 & $0.43-0.67$ & 0.55 \\
\hline $\mathbf{4}$ & FaltiBeliaghata & $6.4-7.12$ & 6.8 & $0.09-0.14$ & 0.11 & $0.51-0.70$ & 0.61 \\
\hline $\mathbf{5}$ & Kritipur-I & $6.32-7.07$ & 6.7 & $0.24-0.30$ & 0.26 & $0.41-0.66$ & 0.54 \\
\hline $\mathbf{6}$ & Kritipur-II & $6.31-7.08$ & 6.6 & $0.18-0.24$ & 0.2 & $0.45-0.52$ & 0.49 \\
\hline $\mathbf{7}$ & $\begin{array}{l}\text { Rohanda- } \\
\text { Chandigharh }\end{array}$ & $6.54-7.14$ & 6.9 & $0.12-0.18$ & 0.14 & $0.35-0.48$ & 0.41 \\
\hline
\end{tabular}

Table.3 Available macronutrient content in soils of different GP of Barasat -II

\begin{tabular}{|l|l|l|l|l|l|l|l|l|l|}
\hline $\begin{array}{l}\text { Sl. } \\
\text { No. }\end{array}$ & $\begin{array}{l}\text { Available } \\
\mathbf{N} \\
\mathbf{( k g / h )}\end{array}$ & Mean & $\mathbf{K}(\mathbf{k g} / \mathbf{h a})$ & Mean & $\begin{array}{l}\mathbf{P} \\
\mathbf{( k g / h a )}\end{array}$ & Mean & $\begin{array}{l}\text { Ca } \\
(\mathbf{p p m})\end{array}$ & Mean \\
\hline $\mathbf{1}$ & Dadpur & $525-600$ & 565 & $230-280$ & 260 & $35-44$ & 39.5 & $425-663$ & 565 \\
\hline $\mathbf{2}$ & Sasan & $315-451$ & 390 & $110-135$ & 120 & $16-20$ & 18 & $325-450$ & 395 \\
\hline $\mathbf{3}$ & $\begin{array}{l}\text { Kemia } \\
\text { Khamarpara }\end{array}$ & $380-450$ & 415 & $120-145$ & 125 & $20-25$ & 23 & $330-459$ & 399 \\
\hline $\mathbf{4}$ & FaltiBeliaghata & $335-421$ & 375 & $100-125$ & 115 & $12-18$ & 15 & $300-380$ & 350 \\
\hline $\mathbf{5}$ & Kritipur-I & $426-480$ & 455 & $125-160$ & 140 & $24-30$ & 26 & $375-550$ & 415 \\
\hline $\mathbf{6}$ & Kritipur-II & $380-430$ & 405 & $110-145$ & 122 & $18-22$ & 20 & $340-462$ & 390 \\
\hline $\mathbf{7}$ & $\begin{array}{l}\text { Rohanda- } \\
\text { Chandigharh }\end{array}$ & $285-345$ & 301 & $90-125$ & 110 & $6-10$ & 8 & $280-345$ & 270 \\
\hline
\end{tabular}

Table.4 Quality parameter of Jute fibre

\begin{tabular}{|c|c|c|c|c|}
\hline \multirow[t]{2}{*}{ SINo. } & \multirow[t]{2}{*}{ GP } & \multicolumn{3}{|l|}{ Quality Parameter } \\
\hline & & Mean Strengths (g/tex) & Mean Fineness(tex) & Grade \\
\hline 1 & Dadpur & 25.1 & 2.5 & $\mathrm{TD}-4+60 \% \uparrow$ \\
\hline 2 & Sasan & 18.2 & 2.8 & $\mathrm{TD}-5+60 \% \uparrow$ \\
\hline 3 & KemiaKhamarpara & 19.9 & 2.6 & TD-4 \\
\hline 4 & FaltiBeliaghata & 17 & 3 & TD-5 \\
\hline 5 & Kritipur-I & 21.9 & 2.6 & $\mathrm{TD}-4+40 \% \uparrow$ \\
\hline 6 & Kritipur-II & 18.5 & 2.7 & $\mathrm{TD}-5+45 \% \uparrow$ \\
\hline 7 & Rohanda- Chandigharh & 16.5 & 2.7 & $\mathrm{TD}-5+20 \% \uparrow$ \\
\hline
\end{tabular}


Fig.1 Location map of study area
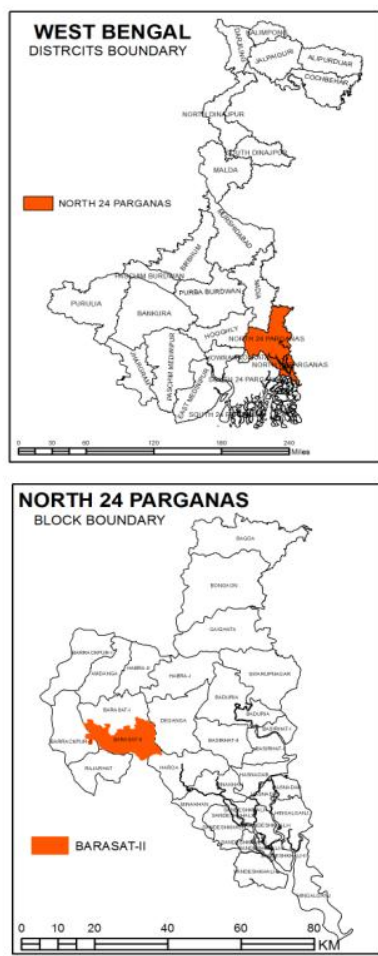

\section{LOCATION MAP OF STUDY AREA BLOCK:BARASAT-II}

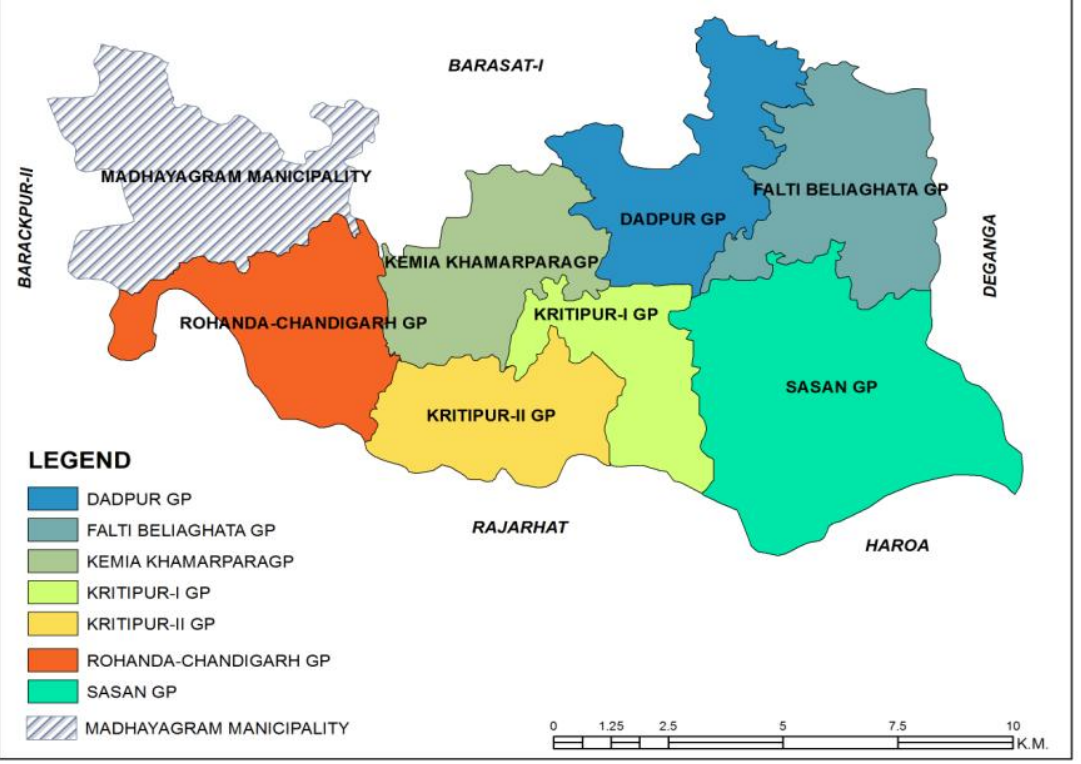

Fig.2 Thematic map of soil $\mathrm{pH}$

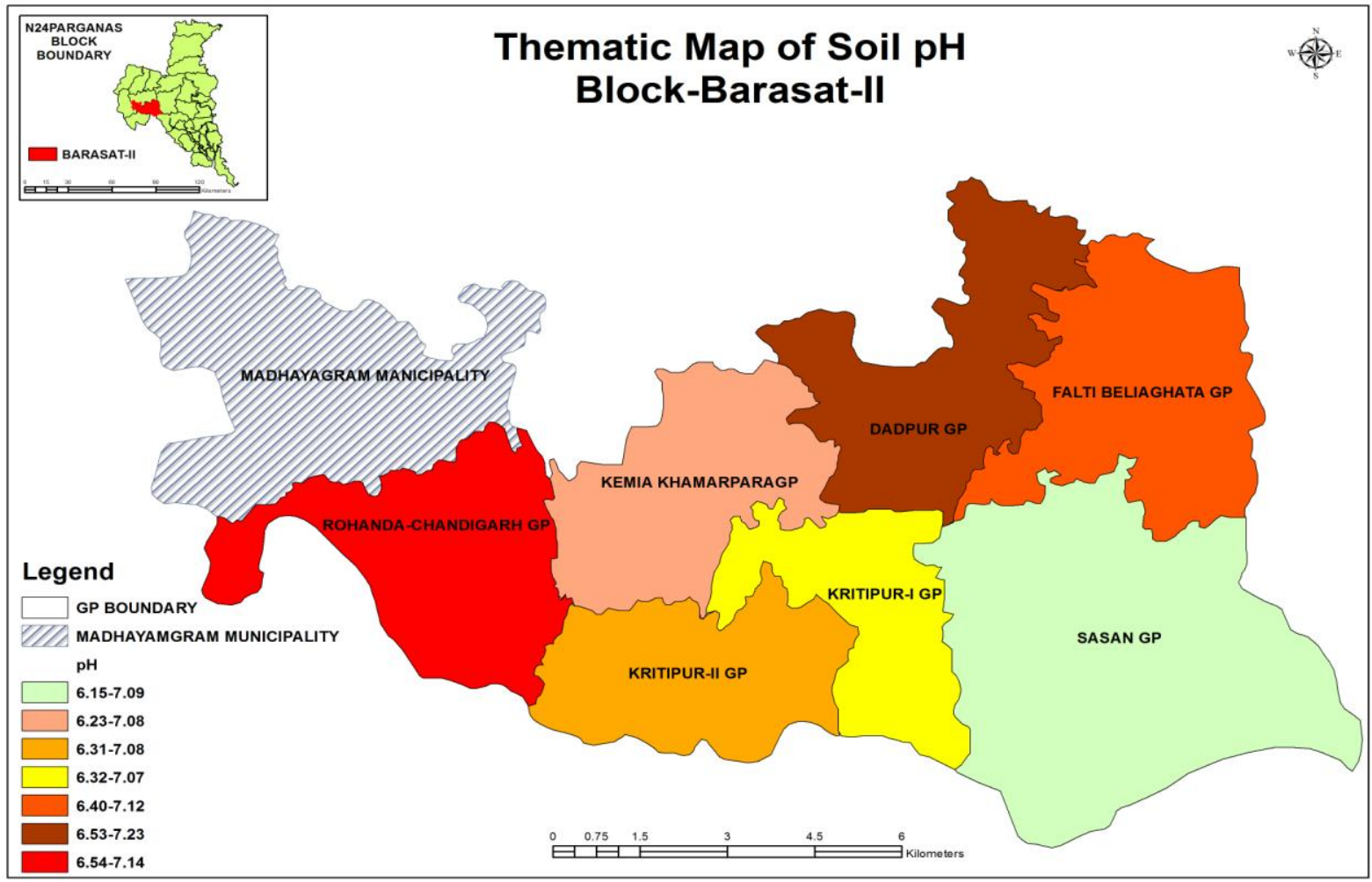


Fig.3 thematic map of soil electrical conductivity

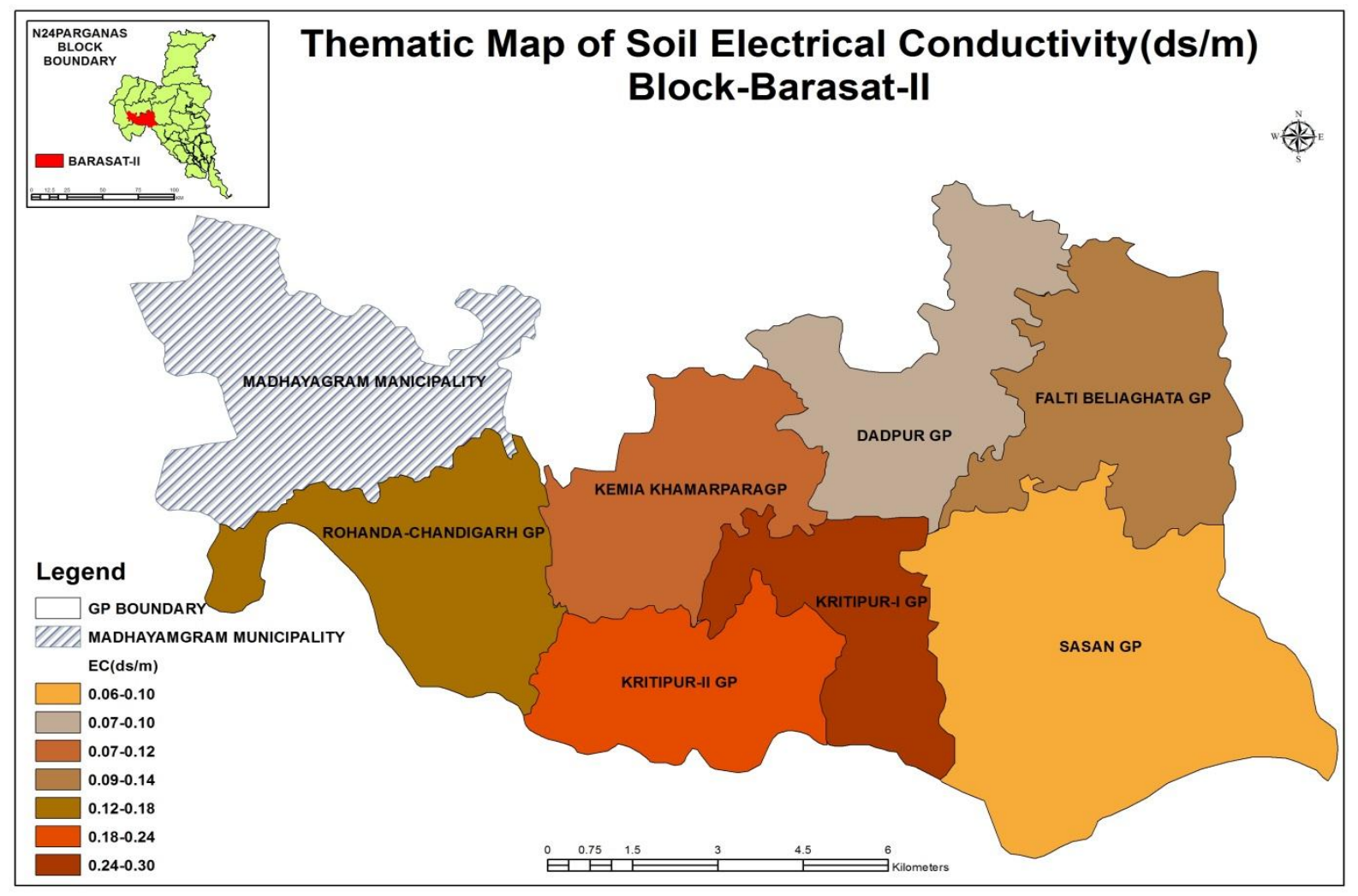

Fig.4 Thematic map of soil organic carbon

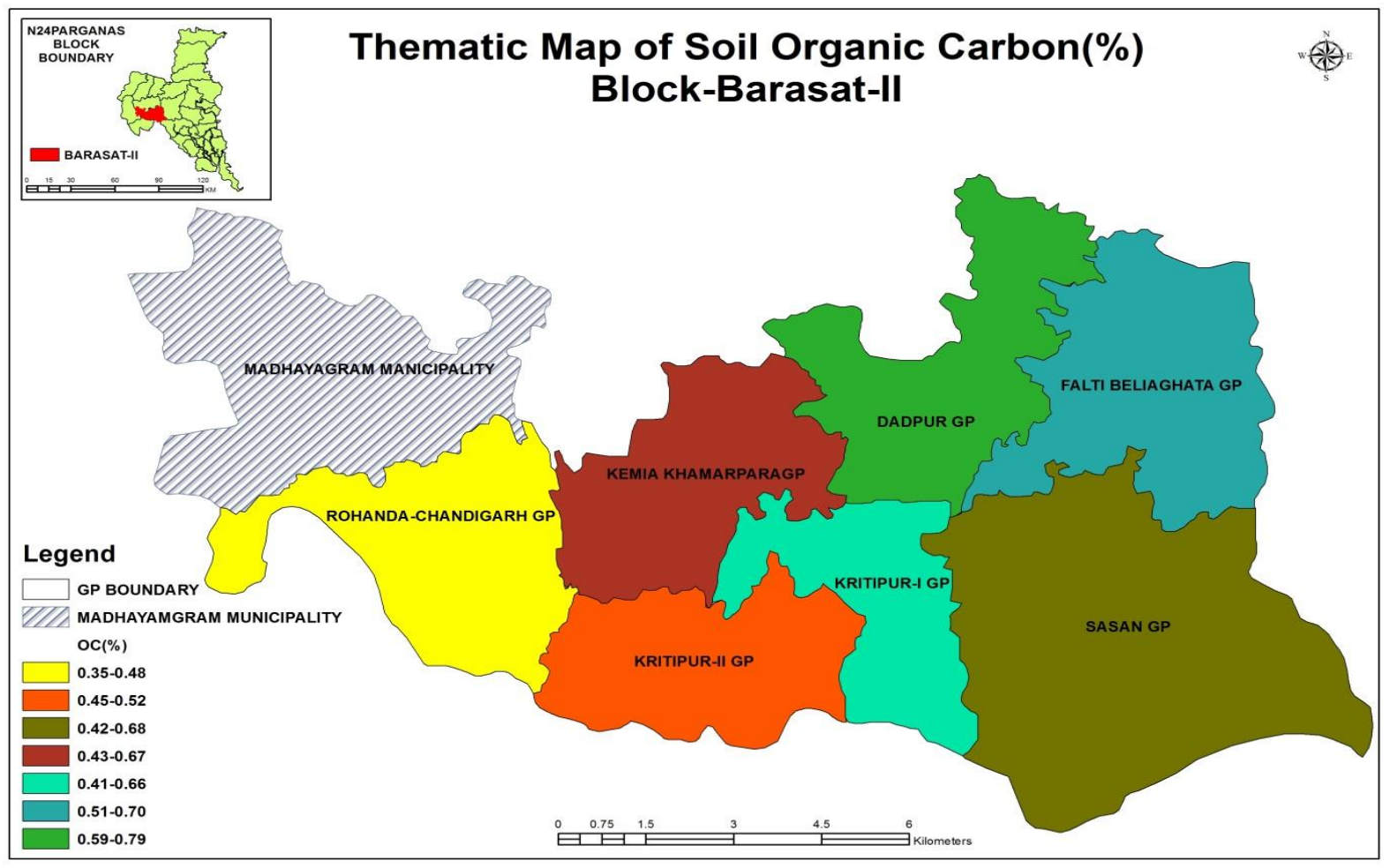


Fig.5 Thematic map of soil available nitrogen

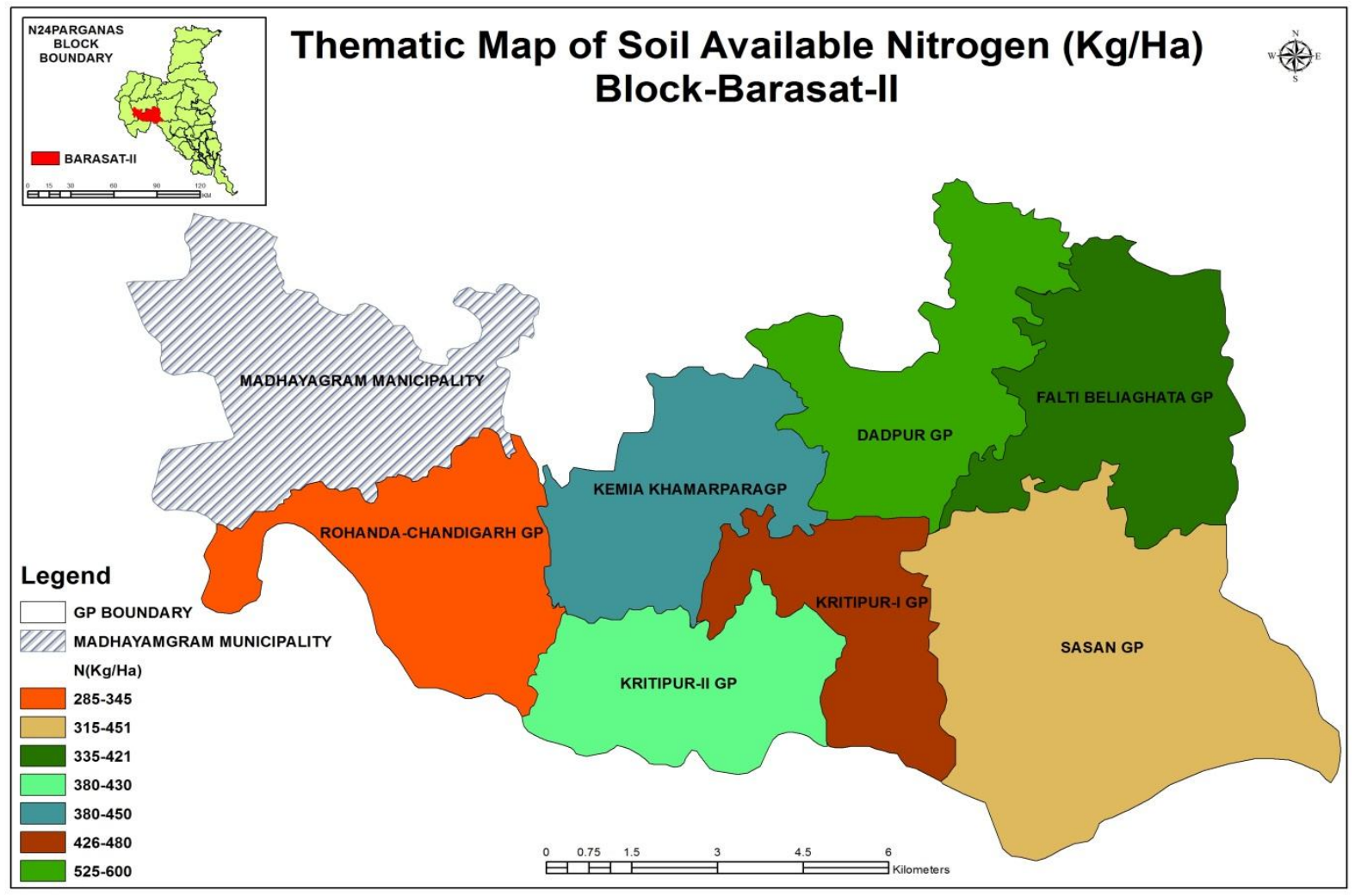

Fig.6 Themetic map of soil available potassium

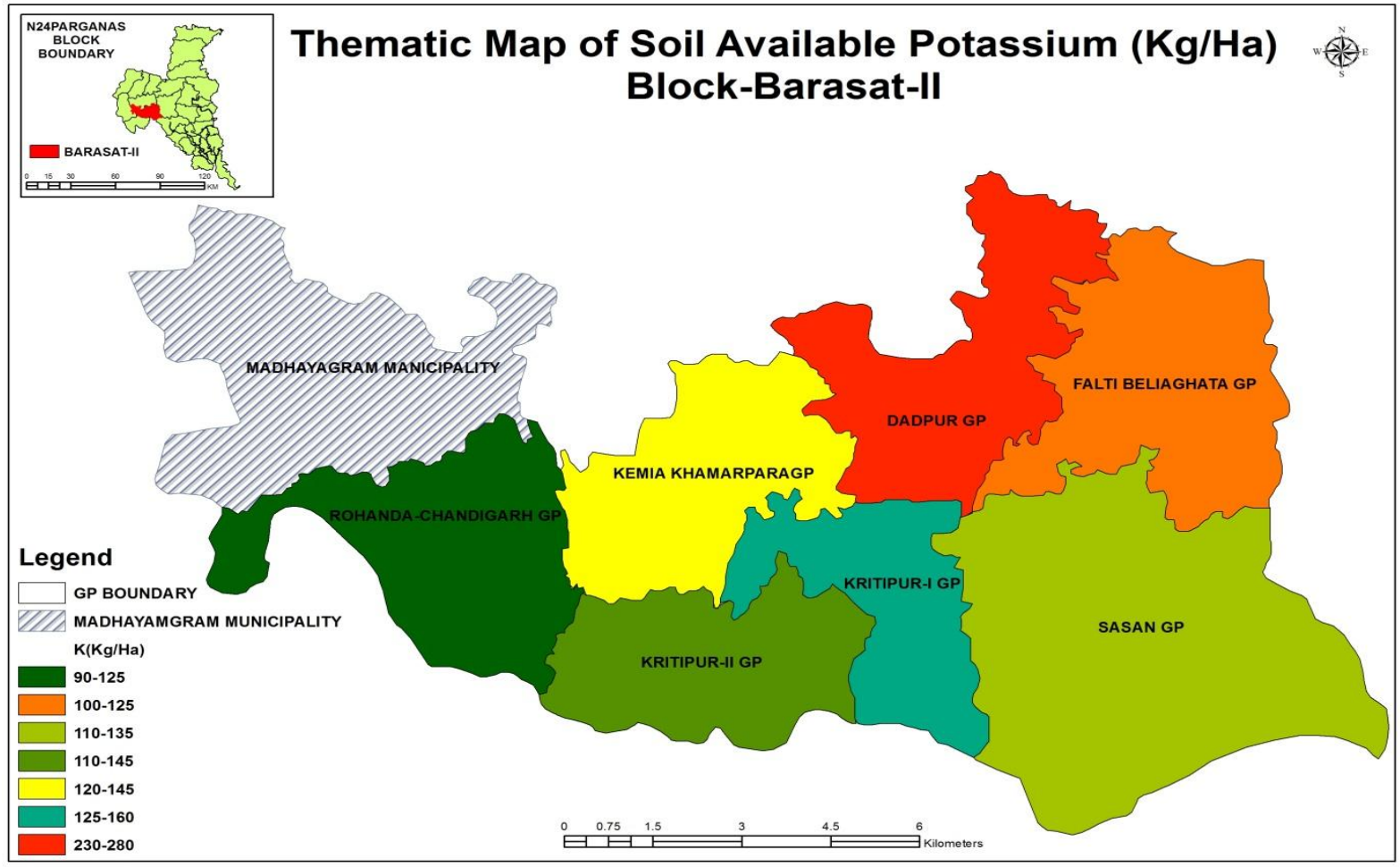


Fig.7 Themetic map of soil available phosphorus

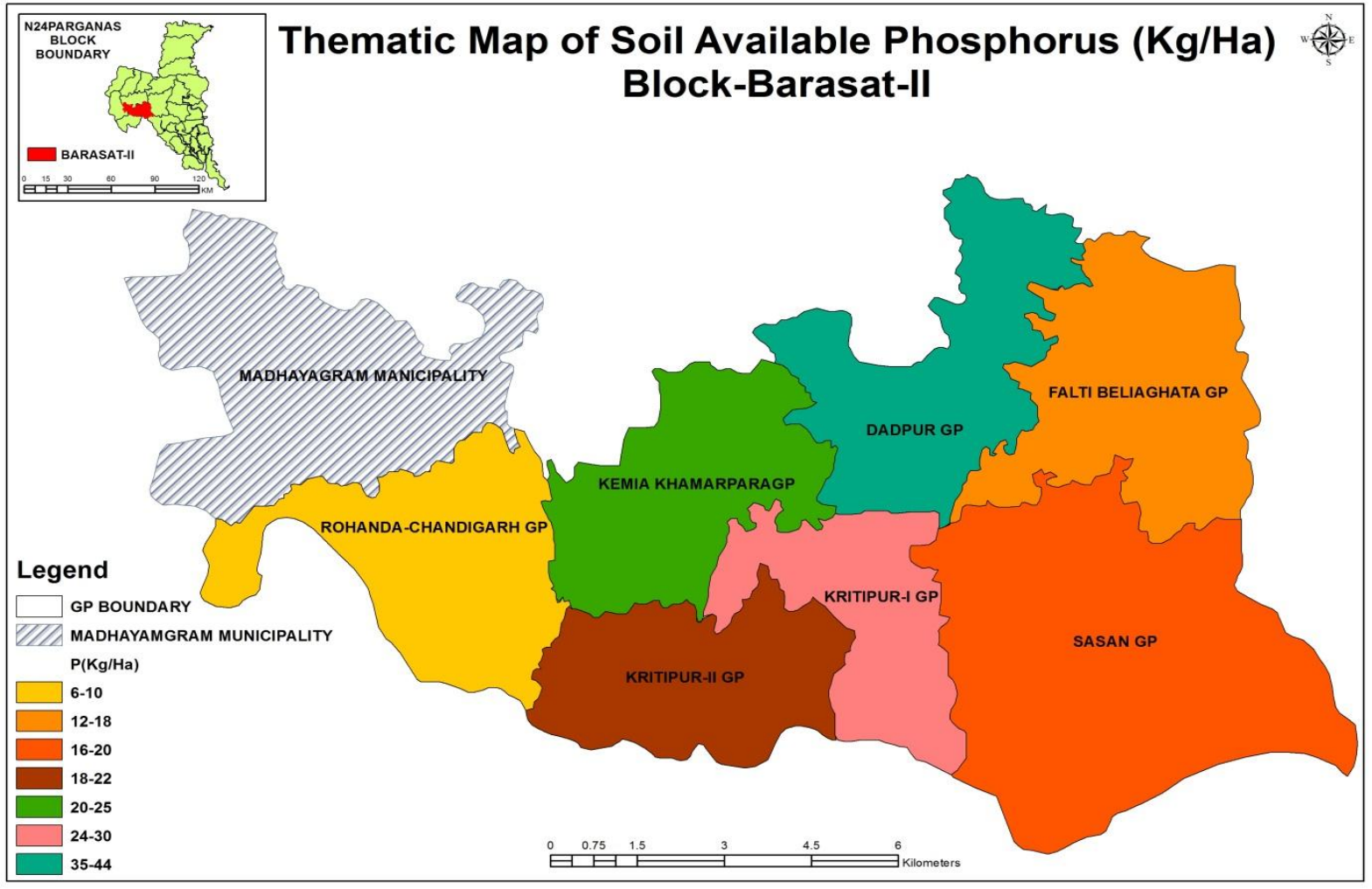

Fig.8 Themetic map of soil available calcium

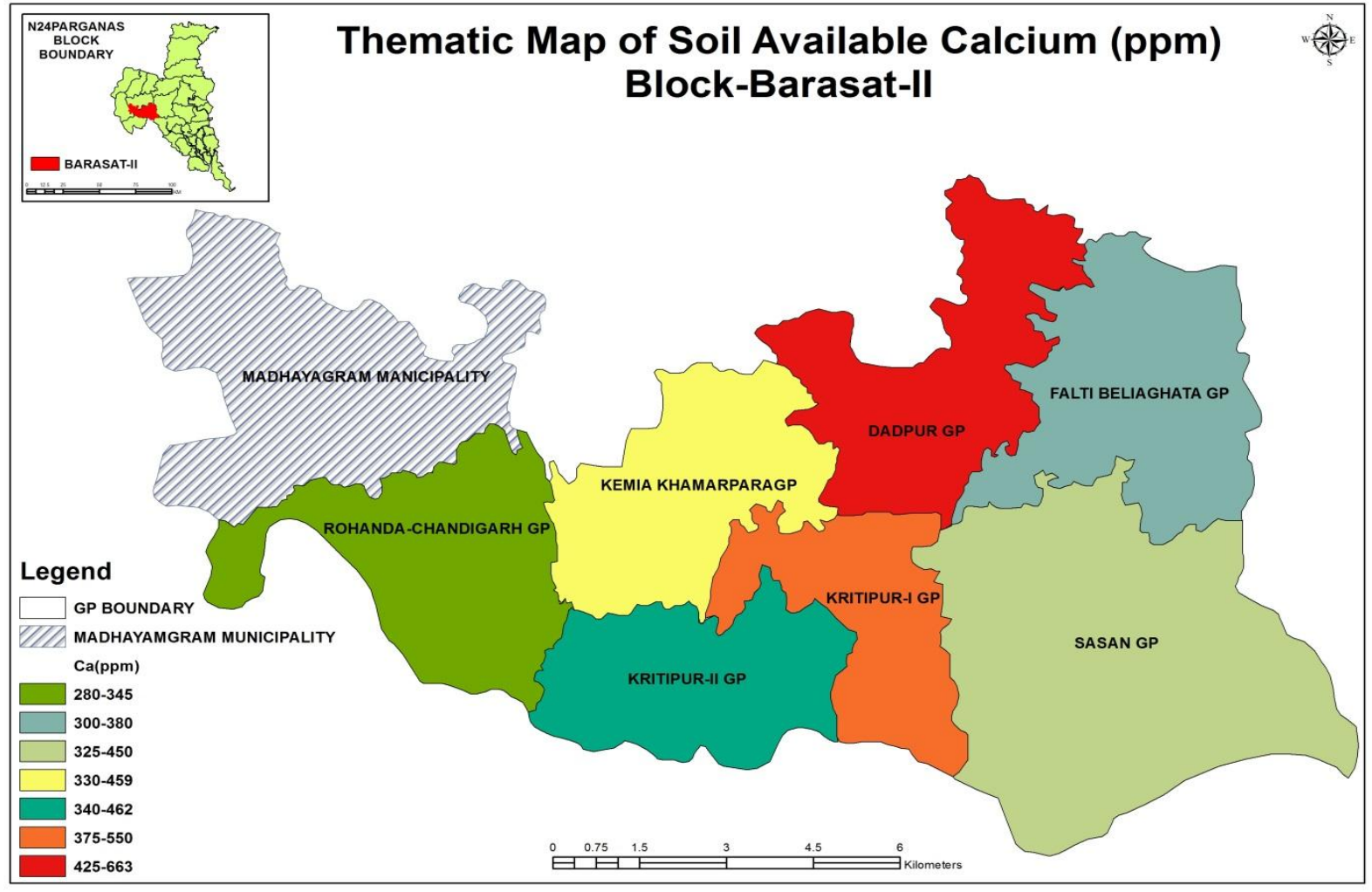


Fig.9 Thematic map of jute fibre strength

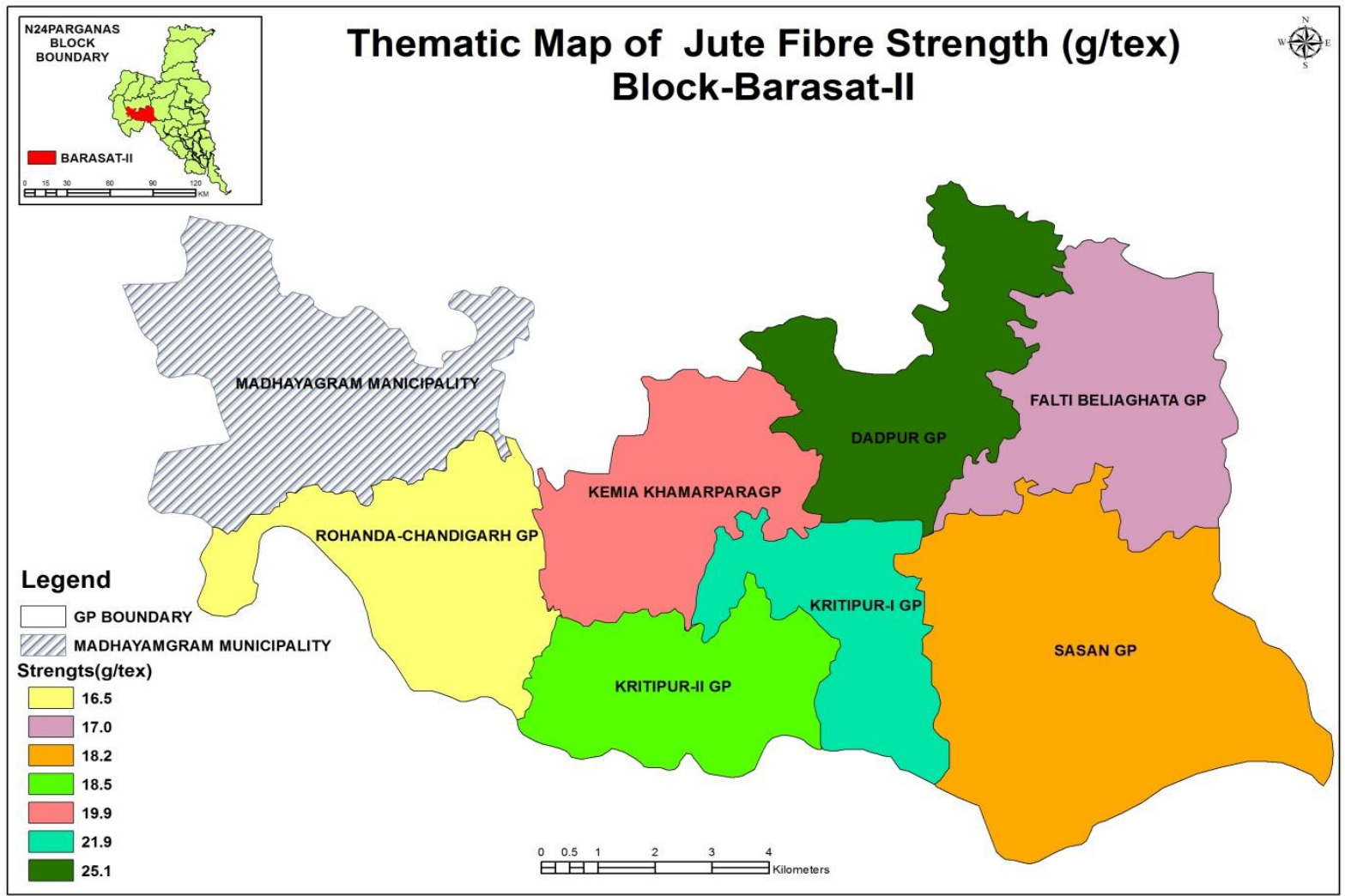

Fig.10 Thematic map of jute fibre fineness

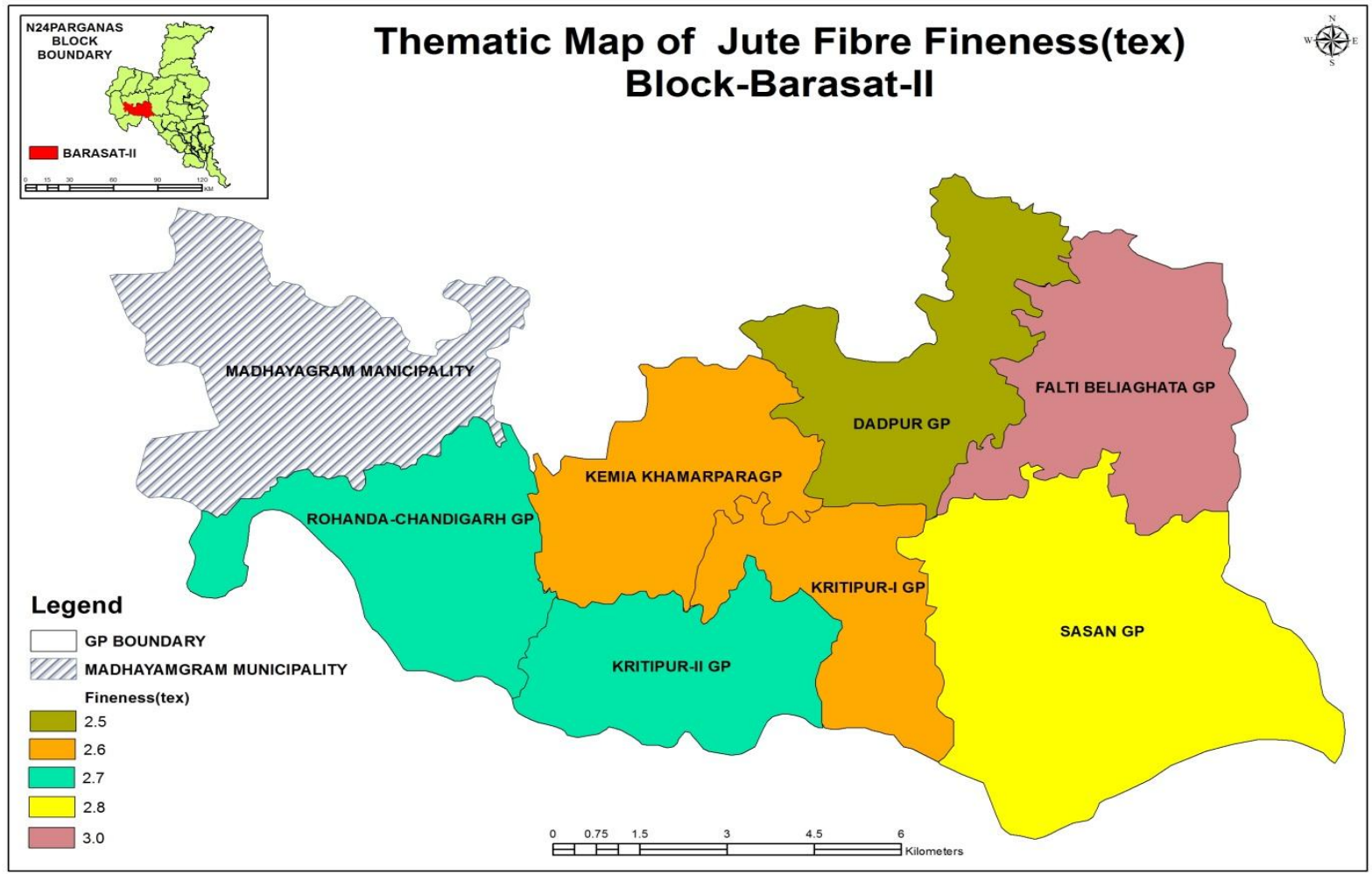


Fig.11 Thematic map of jute fibre grade

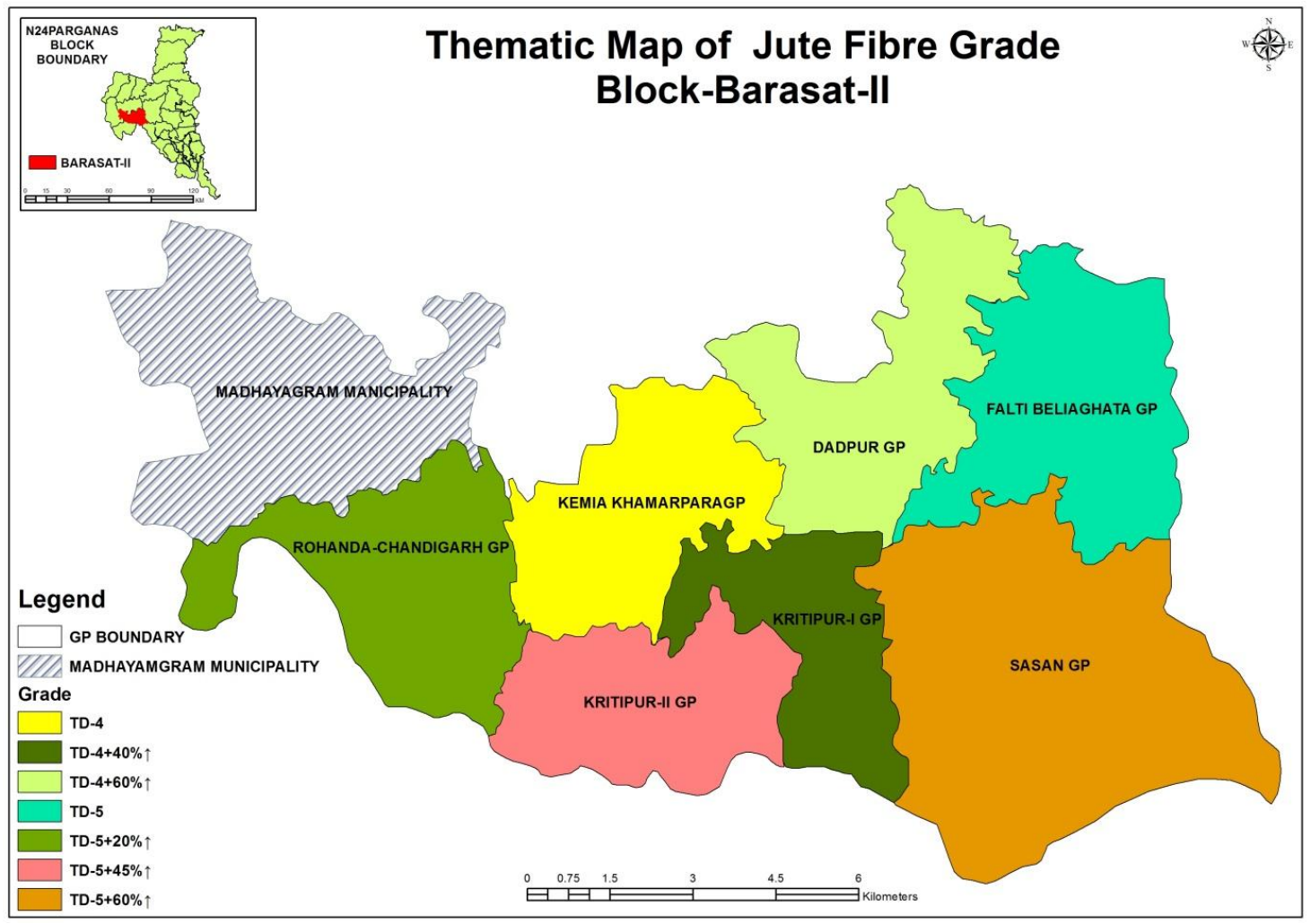

The increase in nitrogen content of the fibre had a positive effect on the cell wall of the fibre and it has significant contribution in increasing fresh and dry fibre yield as reported by Salih et al., (2014). Nitrogen content has positive effect on the fibre quality and mechanical properties in the ramie fibre. Muchow (1990) reported that the photosynthetic capacity of kenaf increased with increasing rate of nitrogen in leaf while Hossain et al., (2010) reported that in kenaf, plant height and photosynthesis were decreased due to nitrogen, phosphorous and potassium deficiency which led to decrease biomass accumulation in plant. Fibre fineness was found to be dependent on organic carbon and available phosphorous content of soil. This observation was at par with the findings of Geitmann and Ortega, 2009. Ping et al., 2004 found that soil phosphorous content affected fibre fineness, length, uniformity and strength and elongation percentage of plant.
The best quality of fibre (TD-4+60\% $\uparrow$ ) was obtained in Dadpur when the maximum N, P, and $\mathrm{Ca}$ content was associated with higher amount of potassium content in soil (Table 3, Fig. 10 and 11).

In conclusion, the study revealed that organic carbon- rich soil of Dadpur GP of Barasat -II block has a direct positive effect on fibre quality of jute. Among soil nutrients, available nitrogen and organic carbon in soil had a strong positive correlation. Available potassium showed positive correlation with the fibre strength. Fibre fineness was found to be mainly dependent on organic carbon and available phosphorous content of soil. The use of GPS receiver and GIS software based technique for soil nutrient survey, fibre samples collection and thematic map generation of respective parameters will help researcher and planners to monitor the temporal and spatial changes in the soil 
fertility and their effect on jute fibre quality. It will facilitate policy makers to take appropriate decision for the comprehensive development of jute sector. This work also can be extended in all the Jute growing blocks of West Bengal for monitoring soil fertility and jute fibre quality to achieve higher Jute crop production.

\section{Acknowledgement}

Authors acknowledge the help of the Director, ICAR-NIRJAFT for providing the facilities to carry out the research work in the laboratory of the institute. Whole-hearted co-operation of the Assistant Director of Agriculture of Barasat Block II is also duly acknowledged.

\section{References}

Ali, R.R., Kotb, M.M., 2010. Use of Satellite Data and GIS for Soil Mapping and Capability Assessment, Nature and Science, 8:8

Arthur, E., Cornelis, W.M., Vermang, J., De Rocker, E., 2010. Amending loamy sand with three compost types: impact on soil quality. Soil Use Manage. 27, 116-123.

Balaghi, R., Tychon, B., Eerens, H., Jlibene, M., 2008. Empirical regression model using NDVI, rainfall and temperature data for the early prediction of wheat grain yields in Morocco. Int. J. Appl. Earth Obs. Geoinf. 10, 438452.International Journal of Engineering Research and General Science Volume 4, Issue 3, May-June, 2016 www.ijergs.org

Basnyat, P., McConkey, B., Lafond, G.R., Moulin, A., Pelcat, Y., 2004. Optimal time for remote sensing to relate to crop grain yield on the Canadian prairies. Can. J. Plant Sci. 84, 97-103.

Bray, R. H., and Kurtz, L. T. (1945). Determination of total organic and available forms of phosphorus in soil.

Soil Science, 59(1), 39-45. https://doi.org/10.1097/00010694194501000-00006.

Department of Agriculture and Cooperation, Ministry of Agriculture, Government of India New Delhi, January, 2011- soil manual guide.

District Statistical Hand Book, Government of West Bengal (Year- 2011)

Districts census Handbook: North Twenty Four Parganas, Directorate of census operations WEST BENGAL

Geitmann, A. and Ortega, J.K.E. 2009. Mechanics and modelling of plant cell growth, Trends Plant Science 14: 467478.

Hofmann-Wellenhof, B., H. Lichtenegger, and J. Collins. Global positioning system: theory and practice. New York, Springer-Verlag, c2001.382 p.

Hossain, D., Musa, M.H., Talib, J. and Jol, H. 2010. Effects of Nitrogen, Phosphorus and Potassium Levels on Kenaf (Hibiscus cannabinus L.)Growth and photosynthesis under nutrient solution, Journal of Agricultural Science. 2(2): 1916-9752.

Human Development Report, North 24 Parganas, Development and Planning Dept, Government of West Bengal (2009).

Manchanda, M.L., Kudrat, M., Tiwari, A.K., 2002. Soil survey and mapping using remote sensing, International Society for Tropical Ecology, pp- 61-74.

Mishra A. and Pattnaik T., Das D. and Das M. (2014) International Journal of Plant and Soil Science, 3 (8), 986-994.

Mishra A., Das D. and Saren S. (2013) Indian Agriculturist, 57 (1), 11-20.

Muchow, R. 1990. Effect of leaf nitrogen and water regime on the photosynthetic capacity of kenaf (Hibiscus cannabinus L.) under field conditions, Crop and Pasture Science. 41(5): 845-852. 
Muralidharudu Y., Reddy S.K., Mandal B.N., Rao A.S, Singh K.N. and Sonekar S. (2001) GIS based soil fertility maps of different states of India. All India Coordinated Research Project on soil test crop response correlation, Indian Institute of Soil Science (ICAR), Bhopal.

Ping, J.L., Green, C.J., Bronson, K.F., Zartman, R.E. and Dobermann, A. 2004. Identification of relationships between cotton yield, quality, and soil properties. Agronomy Journal, 96: 1588-1597.

Reshama M.R. and V.P. Duraisami (2016), Delineation and mapping of soil available Iron and Copper status in Soils of Salem District of Tamil Nadu using GIS techniques, International Journal of Agricultural Sci. and Research, Vol. 6 Issue 2, Apr 2016, Pp. 295-300.

Salih, R.F., Abdan, K. and Wayayok, A. 2014b. Growth responses of two kenaf varieties (Hibiscus cannabinus L.) applied by different levels of potassium, boron and zinc, Journal of Agricultural Science 6(9): 37-45.

Salih, R.F., Abdan, K., Wayayok, A. and Hashim, N. 2014a. Effect of potassium, boron and zinc on nitrogen content in bast and core fibres for two kenaf varieties (Hibiscus cannabinusl.), International Journal of Development Research 4(12): 25812586

Sharma P.K., Sood A., Setia R. K., Verma V. K. (2008) Journal of Indian society of Soil science, 56, $34-41$.

Understanding GIS: The ARC/INFO Method (Redlands, CA: Environmental System Research Institute, 1990), page 1.2:

Vivekananda Aich and More, N. B. (2017), GPS-GIS based soil maps of Micronutrients Status in Organic Farms at College of Agriculture, Pune (M.S.) India, International Journal of current Microbiology and Applied Sciences, Vol. 6. No. 8 (2017) PP. 855-861.

Walkley A. J. and Black I.A. (1934) Soil Science, 37, 29-38.

Walkley, A., and Black, I. A. (1934). An examination of Degtjareff method for determining soil organic matter and a proposed modification of the chromic acid titration method. Soil Science, 37(1), 29-37. https://doi.org/ 10.1097/ 00010694-193401000-00003.

Zhu, A.X. 1999b. A personal construct-based knowledge acquisition process for natural resource mapping using GIS. Int. J. Geographic Information Science 13:119-141.

\section{How to cite this article:}

Saha, Koushik Manna, B., S.C. Saha and Saptarshi Sarkar. 2018. Application of GeoInformatics for Soil Nutrient and Jute Fibre Quality Mapping in Barasat-II Block of West Bengal, India. Int.J.Curr.Microbiol.App.Sci. 7(12): 2854-2866.

doi: https://doi.org/10.20546/ijcmas.2018.712.325 